\title{
Film Induced Tourism: A Study in Indian Outbound Tourism
}

\author{
Nitin Mittal* and G Anjaneyaswamy ${ }^{\dagger}$
}

\section{Abstract}

It is widely believed that nothing unites India more than Cricket and Bollywood. Indian spending on foreign travel has increased to four fold as compared to that in the year 2000. While entire Europe and USA are still struggling to come out of recession, as per an estimate, Indian travellers are expected to grow to 50 million from 9 million. These statistics have enticed tourism boards across the world to find multiple avenues to have maximum share of this ever growing pie. Indian middle class is riding high on its growing affluence, and is exploring new locales and destinations to satisfy its craving for the distinct holiday experience. Indian outbound market is sending strong growth signals to the Tourism Boards and National Tourism Boards (NTBs) globally, who have been experimenting for novel ways to tap this market within their restricted resources. Recent studies by global researchers have established the positive influence of films, on people's travel decisions, especially to the respective locations and destinations featured on the silver screen. With its glossy and larger than life portrayal in the films, some of these destinations have successfully captured the imagination of movie goers and enticed them to visit the places where films are believed to be shot. Unlike the promotional films made for tourism boards, films are considered more authentic as coming

* Research Scholar, Department of Tourism Studies, School of Management, Pondicherry University, India; nitinmittal72@gmail.com

t Department of Tourism Studies, School of Management, Pondicherry University, India; anjaneya.dts@pondiuni.edu.in 
from a third party, hence portrayed with a neutral approach. Through this paper, we have tried addressing the concerns in quantifying the impact of film-induced tourism. We have also covered the factors responsible for hindrance or limiting the impact on destination promotion, which was shown in the particular film.

Keywords: Film, Cinema, Bollywood, Film-tourism, Tourism, Travel, Travel fiction, India

\section{Introduction}

Have you ever experienced an urge to visit the magnificent locales by watching it on silver screen? As per some recent research done in UK, films have been seen as a medium which can influence the destination choice for travellers. As per Macionis and Sparks (2009),

It is possible to speculate that film tourists may be motivated by elements of escape, romance and fantasy, or even a sense of vicarious experience. Cinematic images may influence consumer decision-making processes in terms of motivating visitation to film locations.

Film tourism has been heralded as a positive outcome from destinations featuring in film (Tooke \& Baker, 1996; Riley, et al., 1998; Busby \& Klug, 2001; Croy \& Walker, 2003; Beeton, 2005; Hudson \& Ritchie, 2006; O'Conner, et al. 2008; Cynthia \& Beeton, 2009; Croy, 2010).

Suggested methods to manage film tourism impacts include, increased communication between the Destination Management Organisations (DMOs) and the film industry to promote a cohesive destination image (Bolan \& Williams, 2008; O'Conner, et al. 2008; Cynthia \& Beeton, 2009), and increased awareness of tourist expectations to avoid disappointing experiences (Connell \&Meyer, 2009). Within this context, this literature-based paper aims to review the advent and evolution of film-induced tourism, in Indian perspective, especially for Bollywood.

Indian cinema finally found global mass appeal at the turn of the 21st century. As the world became a global village, the industry reached out further to international audiences. Apart from regular 
screenings at major international film festivals, the overseas market contributes a sizeable chunk to Bollywood's box office collections. Investments made by major global studios such as 20th Century Fox, Sony Pictures and Warner Bros were confirmation that Bollywood had etched itself on the global psyche.

A growing number of Indians are able to afford to take foreign holidays - a total of 12million in 2009 (Lander, 2010).

Till sixties, Bollywood movies have traditionally been shot in the confinement of studios or in Mumbai. Gradually, it moved out to places like Kashmir, Simla and Darjeeling, which became signature and favourite locales of actors and directors, like Shammi Kapoor, B R Chopra and IS Johar to name a few. This was indeed one of the major attractions of cine goers, due to the limited exposure Indians enjoyed at that time in terms of advertising and promotion. Post liberalization in 1990s, with the growth of Indian IT and ITES industry, many of the employees from the middle class started going abroad for both short term and long term. At the same time, Yash Chopra found a success formula with his block buster hit Dilwale Dulhaniya Le Jayenge (DDLJ), where Indian viewers got an opportunity to have a glimpse of Europe and UK from a touristic point of view. There was no looking back for Indian youth from then on. They got umpteen opportunities to realize their dreams of a lifetime, working abroad and globetrotting. This socio-economic change in the earning and exposure also caught the fancy of Global Multinationals, who started recognizing a mammoth pool of Indian middle class spenders. With their growing spending power and shrinking old saving habits, they had more disposable income than ever. Hence, they wanted to experience quality products and services, which were available in abundance.

In the meanwhile, there was a significant slow-down in the world economy, especially in the last decade, with multiple tragedies like 9/11 and other catastrophes. India among the few countries still had much lesser impact; hence all the roads started leading towards this part of the world. Tourism is extremely sensitive to all kinds of volatility, be it political, social or economic, even long spells of bad weather or natural disaster can bring curtains down to the local tourism industry in the affected areas. When there was a 
significant drop in the real estate and consumer spending in US and Europe, Indian tourists who have been insulated so far from the recession have caught attention of National Tourism Boards across the world. These NTOs were looking at some new vehicles for promoting their respective destinations to attract the Indian travellers.

Indian Film industry produces almost double of Hollywood's yearly production. It continues to be one of the most popular sources of entertainment for Indians, often referred to as Cinema and Cricket crazy fans. In 2009, India produced a total of 2961 films on celluloid, that included 1288 feature films and more than 13,000 movies seat a daily rush of nearly 15 million people (Childers, 2002). Many movies are simultaneously released in several of India's 16 official languages. However, the most popular are the Hindi language movies, considering the fact that Hindi is the national language and has a wide base across the country. Although Indian movies have had their presence in the international arena for more than 50 years, Bollywood, as Hindi Film industry is popularly called, has recently become an international phenomenon (Aftab, 2002; Childers, 2002; Dudrah, 2006; Rajghatta, 2008). During the post liberalization phase of Indian economy, post 1990, a new genre of Bollywood movies were made, where the canvas spread beyond Indian locations showcasing offshore destinations.

Bollywood is deep-rooted in the psyche of Indians and the films have a huge influence on Indians when deciding on their next holiday destination (Cineswami, 2012). With a booming economy and expanding middle class, India currently adds approx. 40 million people to its middle class each year, it is certainly a tourism market of great potential. It is being considered as one of the fastest growing markets for the countries like Australia, South Africa, UK, Spain and Ireland in addition to traditional destinations like Dubai, Singapore or Thailand. Most of the Bollywood blockbusters produced in last 2-3 years were filmed at the locales in these countries. There were approximately 9 million foreign trips taken by Indians last year and this number is expected to grow to around 50 million by the year 2020 (Tourism Australia, 2012). 
Films also have a positive impact on tourism, increase place recognition and have a powerful effect on viewers in terms of influencing their next holiday destinations (Baker, 2007). Filminduced tourism has been defined as "tourist visits to a destination or attraction as a result of the destination featured on the cinema screen, video or television" (Busby \& Klug, 2001). Many researchers (Mayo, 1973; Mayo \& Jarvis, 1981) have clearly stated that the perceptions of destinations and the purchase decisions are positively linked, indicating that the image of a destination is a key selection factor (Woodside \& Lysonski, 1989).

Globally, tourism is considered a high-potential sector in terms of its contribution in field of employment generation and economic growth. In recent times, there have been fragmented efforts in the field of Film Tourism research globally and very scant attention focused on to the Hindi Film Industry from India or Bollywood, as it is popularly known. There have been dedicated and committed efforts by various National Tourism Boards to entice Bollywood to film their movies in their respective regions and countries. Most recent example comes across as Zindgi Na Milegi Dobara (ZNMD), where Spanish countryside and its offbeat tourist attractions were given a generous and extensive coverage (Spain wants Indian Tourists, Filmmakers). We may call it the first true "Travel Fiction" from the stable of Hindi Film Industry of India. The film shooting unit is not only a big ticket spender (short term revenue) since they stay for months at various locations, but it also contributes towards the publicity and promotion (long term prosperity), which lure film obsessed Indians to visit such destinations.

Tourism Boards and NTOs have been encouraging the use films as a medium for destination promotion since a blockbuster has a longer shelf life in the minds and hearts of film crazy Indians. New Zealand shot into prominence with Bollywood blockbuster Kaho $\mathrm{Na}$ Pyaar Hai (KNPH). Success of the movie and striking visuals led to an unprecedented tourist rush from India to the Land of Long White Cloud, where authorities had to increase the immigration counter size almost by ten folds. 


\section{Bollywood's Influence on Tourism}

While a picture speaks a thousand words, a video speaks a million! And Bollywood impacts almost a billion of its ardent fans and followers spread across the globe.

With Indians living in most of the habitable places on the earth, Bollywood or Indian Hindi Film Industry has become a religion of masses, irrespective of race, cast or creed. Films have been an integral to Indian household, since independence, when they were gradually accepted as a moral medium of entertainment for the family as a whole. Actors have enjoyed unparalleled popularity, more than anyone else, be it a sports star, business person or politician.

In the centenary year of Indian Film industry, it is established that Bollywood has a big influence on Indians when choosing their next holiday destination. Once Indian films moved out of studio setting, locales like Patnitop in Kashmir had become a major honeymoon resort due to the umpteen love songs filmed there in the sixties and seventies. People from all over the country used to throng to Queen's Necklace at Marine Drive or Juhu Chowpatty, which symbolized Mumbai in films. Internationally, Switzerland's exposure in Indian films made it one of the most sought after destinations, for both film-makes as well as Indian tourists, in last four decades. So much is the influence of Indian film tourism in Switzerland; one could even have Indian meals with a menu in Indian languages there. Another Bollywood blockbuster of 2000, Kaho Na Pyaar Hai (KNPH), shot extensively in New Zealand, sent an unprecedented wave of Indian tourists there, forcing them expanding the immigration counter to 5,000 sq. ft. from original 500 square feet.

Raj Kapoor was one of the first Indian directors to shoot a Bollywood film in an international location when he filmed part of his 1964 hit, Sangam, in foreign locales like Venice, Paris and Switzerland (First foreign treat, 2012).For more than forty years, Bollywood's producers and directors have favoured the pristine backdrop of Switzerland for their films and made it a favourite international destination featured in Bollywood movies. One of the most famous of the Bollywood filmmakers of recent times, Yash 
Chopra, made a point of including this fairy land in virtually all his films. He had covered its high Alpine meadows, shot around its serene lakes, and shown his main protagonists romancing in its charming towns, to convey an ideal of sunshine, happiness and tranquillity. In the process, he had created an enormous curiosity about things Swiss in the generations of middle-class Indians, who are now affluent enough to travel there in search of their dreams. Swiss tourism officials and their Indian counterparts have been wisely capitalizing on their obsession. Number of nights spent by Indian tourists in Switzerland, who travel mostly in summers, has gone up to 350,000 annually.

Another trend started with Dilwale Dulhaniya Le Jayenge (DDLJ) in the 90's, showcasing beautiful landscapes of Europe, from Britain to Swiss country-side. The horizon was further widen with Bollywood intruding into new territories like Poland and Finnish Lapland of Rovaniemi (Fanaa), Korea (Gangster), Victoria in Australia (Salaam Namaste), Brazil (Dhoom II), Scotland and Cuba (EkTha Tiger), Ras Al Khaimahin UAE (Deewane Hue Pagal, 36 China Town), Malaysia (Don II) and South Africa (Race).

\section{Reliving Bollywood through Film-Induced Tourism}

In a country like India, it has been well established that Bollywood films do help in selling holidays. While Spain has been amongst the biggest tourism destinations worldwide, but never been a popular choice for Indians as an exclusive destination. However, egged by the popularity of 2011 Bollywood blockbuster, ZNMD, one of India's leading tour operators, SOTC, started a seven-day Spain package, highlighting the La Tomatina festival and other adventurous activities depicted in the film, a maiden effort by any Indian company to organize a trip to the international festival made popular by a film. ZNMD's influence is evident as companies are getting increased queries from couples and youngsters, who want to try adventure and experience its culture as shown in this film.

One of the best and unique tributes to Bollywood and Yash Chopra was given by Swiss Tourism when they started a special tour called Enchanted Journeys, ranging from seven to nineteen days (Tagliabue, 2010). This tour, launched in 2010, gives the travellers 
an opportunity to visit all the Swiss locales where Yash Raj Films (YRF) was shot, including Chandni, Darrand and DDLJ. During this twelve-day trip, travellers get the opportunity to watch the DVDs of prominent YRF film scenes, shot in Switzerland, while travelling from site to site, to relive their favourite Swiss moments. Since its launch, Enchanted Journey has already got more than seventy enrolments.

Another example, with the success of "Krissh" in 2006, Singapore Tourism Board had launched a special tour package named after the movie (TNN, 2006). It was the first big budget Bollywood film shot extensively in Singapore, highlighting its main tourist attractions like Sentosa Island, Singapore Zoo in addition to its skyline full of sky scrapers. Even neighbouring Hong Kong Tourism Board has plans to develop a dedicated tour packages with locales and attractions featured in Bollywood films.

Britain got immensely benefited with Bollywood blockbusters like DDLJ, Pardes, Kabhi Alvida Na Kehna and Namaste London. One of the most popular filming destinations for Bollywood, other than Switzerland, Indian films are worth approximately GBP 20 million annual revenue to London's economy. British Tourism Authority is pitching high on Bollywood through innovative "Bollywood Map of Britain", targeting Indian tourists who would be like to make a pilgrimage there. It covers locations like the Waddesden Manor and Blenheim Palace, used extensively for the shooting of Kabhie Khushie Kabhie Gham (K3G) and other spots got famous by their repeated occurrences in Bollywood movies. This move would allow Bollywood buffs to walk the paths of the now famous British locales and relive their favourite Bollywood moments.

Hong Kong government has established a Television and Entertainment Licensing Authority (TELA) to facilitate filming services and act as Single Point of Contact (SPOC) for the production houses (Chu, 2009). Many Bollywood films already were shot in Hong Kong, like Naam, Gumrah, Company and Awaraapan. Hong Kong Tourism Board and TELA are focusing on Indian film makers to use the diverse locales of their city as shooting backdrops. Their strategy seems to be working as in 
recent times; Hong Kong has recorded a 24.7 per cent growth in Indian visitors (Gursahani, 2008).

\section{All the Roads Lead to Bollywood}

Bollywood is the most popular definition of the Hindi films from India. Selling almost double the tickets annually than Hollywood, it showcases themes from all over the world. Hence, it has become an emerging battle among Tourism Boards to rope in to the Bollywood saga.

Over the past two decades, Indian film industry and Bollywood in particular, has been going places, quite literally. Films are being shot globally, from neighbouring Sri Lanka to distant New Zealand to UAE, Egypt, South Africa, UK and USA. In its wake, the footfalls in the respective locations that the films been shot at have multiplied over time. Close on the heels of these successes are international tourism boards, who have seized every opportunity to showcase the 'must sees' and 'must do's' in their respective regions. Tourist organisations are competing against each other whilst trying to seduce Indian tourists to be attracted to their specific destination or attraction. In recent times, nearly every international tourism board that entered the Indian market tried wooing the Bollywood by providing incentives, hassle-free single window clearances and even assistance in conducting a reconnaissance of probable locations.

The success of Switzerland in Bollywood has now enticed newer entrant, like Finnish Tourism Board (FTB), to organize the tours for Bollywood's film production teams to familiarize them with the Finnish landscape. In addition to the easy permission and other non-tangible benefits, FTB has also proposed location subsidies for Bollywood. Their idea is to sell the Land of Midnight Sun to Indian tourists by bringing it under Bollywood's arch lights. With the advantage of having a direct flight between Helsinki and India, FTB should expect a trail of Bollywood fans reaching Santa's land for their holidays. Helsinki City Tourist and Convention Bureau is offering assistance to Film units in dealing with practical issues such as site selection and even closure of streets for certain film shoots. FTB is in the process of setting up a dedicated film commission to aid foreign film productions. A Bollywood 
blockbuster could generate for Finland the awareness that would otherwise take many years being relatively new destination.

Buoyant with the success of films like 'Kal $\mathrm{Ho} \mathrm{Na} \mathrm{Ho'} \mathrm{and} \mathrm{'Kabhi}$ Alvida Na Kahna', in October 2008, representation from Mayor's Office of Film, Theatre and Broadcasting (MOFTB) New York, came to meet the leaders of India's film industry. The goal behind this outreach was to highlight the benefits of filming in New York which would ultimately result in increased tourist inflow from India. MOFTB acts as a one stop shop for all production needs in New York City, including free permits, free public locations and free police assistance to production companies and film houses.

Another delegation from Tourism Ireland visited India, in early 2012 , to meet with key tour operators and film production teams, to ensure their continued share from this emerging tourism market. Tourism Ireland has been capitalizing on the success of Bollywood blockbuster, EkTha Tiger, shot in Dublin in 2011 and watched by over 20 million people in India alone. With the footage shot in Dublin, Tourism Ireland hopes to generate enough curiosity among Indians, resulting in increased footfalls to the filming locations (Ryan, 2012).

Interestingly off-beat destinations like Fiji, Ukraine, Muscat and Israel have expressed their keen interest in roping in the Indian films industry as well. A rebate of $47 \%$ on local spend is offered by Fiji Tourism Commission to shoot at its 315 Virgin Islands (Novaro, 2011). Poland, where parts of the film Fanaa were shot, is making efforts to tap Bollywood production houses, realizing the power and influence of Bollywood's magic on Indian tourists. Even the Latin American countries like Brazil and Colombia have been trying to woo Indian Film industry, despite logistic challenges, in terms of distance and lack of convenient air connectivity. Cuba has tasted its first success when part of Ek Tha Tiger was shot at its locales, capturing its rich lifestyle along with the scenic beauty.

According to the estimates drawn by Tourism Australia, about 50 million Indians are expected to travel overseas by 2020. India, one of the world's fastest growing outbound travel markets, is a toast of international tourism boards. When the world is still reeling under the effects of recession, tourism has been a big focus for most of the 
governments like USA, which is making all possible efforts to encourage inbound tourism industry that provides one of the highest direct and indirect employment ratios to the local population. Australian government has also set its eyes on to Indian outbound tourist despite the air connectivity between the two countries being under-served with no direct non-stop flights. Preliminary analysis suggests that they would require an additional 345,000 seats by the year 2020 to cater to the expected demand for Australia from India. Indian arrivals to Australia have grown at a healthy compound annual growth rate (CAGR) of 12.3 percent over the last decade. Indian market ranks as tenth inbound tourist market for Australia with around 148,000 visitors spending 867 million Australian dollars in 2011 alone. One of the world's fastest growing outbound travel markets, India could rise in annual value to up to 2.3 billion Australian dollars and deliver 300,000 visitors annually, by the year 2020 (Tourism Australia, 2012).

\section{Challenges}

Films do have substantial impact on tourist choice of destinations but may not be the sole factor. Logistic framework like air connectivity and political stability also play an important role before finalizing on the preferred holiday destinations. Despite Bollywood films being shot in Cuba, Greece, Prague, Estonia and Russia, the above factors do pose major hindrances in making them a practical destination to travel. While travel to Spain is getting momentum with the success of ZNMD, a direct flight from major Indian gateway cities may swell these numbers, especially for youth and honeymooners.

Traditionally songs and dances have been integral to Bollywood films and they are often pictured in foreign locales. Some of these attractions have 'blink and you miss' appearance and difficult to register in viewers mind. Unless part of a specific storyline, there are no references made of such locations in the film, hence difficult for the viewers to identify the place, unless a prominent tourist attraction. Therefore tourism boards of Finland and Helsinki have made it clear to scrutinize the film scripts or story-line, in order to offer any assistance, to ensure proper recognition to their land and its attractions which would result in reaching the target viewers. 
In Indian context, holiday or vacation is a family decision. A typical Indian family consists of four persons and both parents and children choose a destination suiting to their liking and requirements. Not all the films made in recent times are found suitable for viewing by Indian family as a whole, as some of the content may not be conducive for the Indian value system. In this entire game, the losers may be tourism boards who despite putting all the efforts in promoting their respective attractions may not receive the enough eyeballs.

Another challenge would be the limitations in quantifying the absolute numbers generated by film tourism alone. In the first scenario, the particular location or attraction may be already famous and frequented by tourists, like Eiffel Tower or Statue of Liberty. In such case, it would be difficult to ascertain if increase in tourist arrival was due to the impact of film's success which was shot at these spots or locales were chosen due to their fame. We may term it a typical case of 'Chicken and Egg Syndrome'. Even in the case where a relatively new destination or attraction started getting more footfalls after its depiction in one of the blockbuster, there could be other factors responsible like accessibility or affordability along with its fitment in the tourist itinerary.

\section{Research Methodology, Findings and Suggestions}

Academic research on film tourism has been around since the early 1990s, but the popularity and extensiveness of research in this area has increased in recent years (Beeton, 2010), with a number of studies examining the increase of visitor numbers to film locations (Beeton, 2005; Busby, Brunt, \& Lund, 2003; Croy \& Walker, 2003; Riley, Baker, \& Van Doren, 1998; Riley \& Van Doren, 1992; Tooke \& Baker, 1996).

Tookes and Bakers' (1996) study concentrated on effects of motion picture film on tourism through material from academic researches, journals and newspapers. In case of Bollywood, there is hardly any study or material is available on Film Induced Tourism. Most of the information available on internet is in the form of various articles and news items, courtesy independent writers as well as National Tourism Board. 
Table 1. Forms and characteristics of movie tourism:

\begin{tabular}{|c|c|}
\hline Form & Characteristic \\
\hline \multicolumn{2}{|r|}{ On-Location } \\
\hline $\begin{array}{l}\text { Movie tourism as primary } \\
\text { travel motivator }\end{array}$ & $\begin{array}{l}\text { The movie site is an attraction in its own right } \\
\text { - strong enough to motivate visitation }\end{array}$ \\
\hline $\begin{array}{l}\text { Movie tourism as part of a } \\
\text { holiday }\end{array}$ & $\begin{array}{l}\text { Visiting movie locations (or studios) as an } \\
\text { activity within a larger holiday }\end{array}$ \\
\hline Movie tourism pilgrimage & $\begin{array}{l}\text { Visiting sites of movies in order to "pay } \\
\text { homage" to the movie; possible re-enactments }\end{array}$ \\
\hline Celebrity movie tourism & $\begin{array}{l}\text { Homes of celebrities; movie locations that } \\
\text { have taken on celebrity status }\end{array}$ \\
\hline Nostalgic movie tourism & $\begin{array}{l}\text { Visiting film locations that represent another } \\
\text { era }\end{array}$ \\
\hline \multicolumn{2}{|r|}{ Commercial } \\
\hline $\begin{array}{l}\text { Constructed movie } \\
\text { tourism attraction }\end{array}$ & $\begin{array}{l}\text { An attraction constructed after the filming } \\
\text { purely to attract/serve tourists }\end{array}$ \\
\hline Film/Movie tours & Tours developed to various movie locations \\
\hline $\begin{array}{l}\text { Guided tours at specific } \\
\text { on-location set }\end{array}$ & Tours of specific sites, often on private land \\
\hline \multicolumn{2}{|r|}{ Mistaken Identities } \\
\hline $\begin{array}{l}\text { Movie tourism to places } \\
\text { where the filming is only } \\
\text { believed to have taken } \\
\text { place }\end{array}$ & $\begin{array}{l}\text { Movies and TV series that are filmed in one } \\
\text { place that is created to look like another; of-ten } \\
\text { in other countries for financial reasons; known } \\
\text { as runaway productions }\end{array}$ \\
\hline $\begin{array}{l}\text { Movie tourism to places } \\
\text { where the movie is set, } \\
\text { but not filmed }\end{array}$ & $\begin{array}{l}\text { The movies have raised interest in a particular } \\
\text { country, region or place, where the story is } \\
\text { based, not where it was actually filmed }\end{array}$ \\
\hline \multicolumn{2}{|r|}{ Off-Location } \\
\hline Movie studio tours & $\begin{array}{l}\text { Industrial tours of working movie studios, } \\
\text { where the actual filming process can be } \\
\text { viewed. }\end{array}$ \\
\hline Movie studio theme park & $\begin{array}{l}\text { Usually adjacent to a studio, specifically built } \\
\text { for tourism with no actual filming or } \\
\text { production taking place }\end{array}$ \\
\hline \multicolumn{2}{|r|}{ One-off Events } \\
\hline Movie premieres & $\begin{array}{l}\text { Particularly those outside traditional sites such } \\
\text { as Hollywood }\end{array}$ \\
\hline Movie festivals & $\begin{array}{l}\text { Many cities hold movie festivals that attract } \\
\text { movie buffs and fans for the event }\end{array}$ \\
\hline
\end{tabular}

Hence we have used the internet liberally to substantiate the numbers and influence. This paper concentrates on the theoretical 
issues and previous studies related to movie-induced tourism. Since only a limited amount of literature is available on movieinduced tourism scenario in India, through this research paper, we have tried establishing connect between the movies and their influence on tourist's choice of destination. We have taken Indian Hindi movies (or Bollywood) journey from Studios to the Outdoors with the reasoning behind the move. This paper also covers the changes or evolution of Indian middle class and its influence on Bollywood as well as film makers selection of filming destination(s) or vice versa. Films or movies as they are now commonly referred to while not produced with the prime intent of inducing people to visit destinations as tourists nonetheless enhance the awareness, appeal and profitability of locations through the power of imagery and fantasy of story that they portray (Macionis, 2004). A growing body of evidence from authors such as Hudson and Ritchie (2006), Beeton (2005), Riley et al. (1998), Tooke and Baker (1996) and Butler (1990) support this phenomenon of tourists visiting particular destinations because of their association with particular films.

Films or movies provide us with a window into other places that broaden our knowledge and can fuel our desire to travel. Further, films are not always shot in the place where they are portraying on screen. This has become a common occurrence (especially in countries such as Ireland) and it is not unusual for a film to be made in a completely different country from that it portrays. In Bollywood film such occurrence are regular, such as movie like'Hum Dil De Chuke Sanam', where Hungary (Budapest) has been shown as Italy.

\section{Conclusion}

The main purpose of movies is not to promote filming locations as tourist destination, but several studies around the world have shown that people are attracted to the locations that they have seen in movies (Riley \& Van Doren 1992; Tooke \& Baker 1996; Riley, Baker \& Van Doren 1998; Busby \& Klug 2001; Iwashita 2008).

One of the key indicators of the rise in number of Indians with higher disposable income is the surge in number of outbound travellers from India. In the past, Indians were travelling to 
traditional destinations like Singapore, Thailand, Sri Lanka, Malaysia and UAE, in addition to USA and UK that had been frequented on account of friends and family travel. However there has been a growing interest among travellers to newer destinations like Spain, Scotland, Australia, New Zealand and South Africa. Closer probes by the tourism industry professional have revealed that Bollywood movies shot in these locales are instrumental in enticing tourists to realize their favourite celluloid dreams.

Although most motion picture films are not produced with the prime intent of inducing people to visit locations, it has been stated that this medium can enhance the awareness, appeal and profitability of locations through the power of imagery and the fantasy of the story (Riley \& Van Doren, 1992; Couldrey, 1998; Beeton, 2001; Croy \& Walker, 2003).

Films are a fantastic vehicle to promote a destination. There are four factors where films score in destination promotion: free advertising for the destination; gives more authenticity against the hard-selling factor of official media campaigns; reaching a wide target audience and address deep, intrinsic feelings and connect them with a real place (Roesch \& Stefan, 2009).

\section{References}

Aftab, K. (2002). Brown: The new black! Bollywood in Britain. Critical Quarterly, 44(3), 88-98. doi/10.1111/1467-8705.00435

Baker, B. (2007). Destination branding for small cities: The essentials for successful place branding. (1sted.). Portland, Oregaon: Creative Leap Books.

Bandhopadhyay, R. (2008). Nostalgia, identity and tourism: Bollywood in the Indian diaspora. Journal of Tourism and Cultural Change, 6(2), 79100. doi/10.1080/14766820802140463

Beeton, S. (2001). Smiling for the camera: The influence of film audiences on a budget tourism destination. Tourism Culture and Communication, 3(1), 15-25.

Beeton, S. (2005). Film induced tourism (aspects of tourism). (1 ${ }^{\text {sted.). }}$. Bristol, UK: Channel View Publications.

Busby, G., \& Klug, J. (2001). Movie-induced tourism: The challenge of measurement and other issues. Journal of Vacation Marketing, 7(4), 316332. doi.org/10.1177/135676670100700403. 
Childers, H. M. (2002)."You go girl!" Nationalism and women's empowerment in the Bollywood film KyaKehna! (Doctoral dissertation, Faculty of the Louisiana State University and Agricultural and Mechanical College in partial fulfilment of the requirements for the degree of Master of Arts in The School of Art by Hope Marie Childers BFA, Louisiana State University). Retrieved from http://etd.lsu.edu/docs/ available/etd-0411102-131419/unrestricted/Childers_thesis.pdf.

Chu, Y. (2009). Hong Kong cinema: Coloniser, motherland and self. (1 $1^{\text {sted.). }}$ London: Routledge Chapman \& Hall.

Cineswami. (2012, Feb 23). Cuba, Ireland milk Salman Khan's 'Ektha Tiger' magic. Retrieved from http://www.bollywoodlife.com/newsgossip/cuba-ireland-milk-salman-khans-ek-tha-tiger-magic/.

Connell, J., \& Meyer, D. (2009). Balamory revisited: An evaluation of the screen tourism destination-tourist nexus. Tourism Management, 30(2), 194-207. doi/10.1016/j.tourman.2008.06.001.

Couldry, N. (1998). The view from inside the "simulacrum": Visitors' tales from the set of Coronation Street. Leisure Studies, 17(2), 94-107. doi/10.1080/026143698375178.

Croy, W. G. (2010). Planning for film tourism: Active destination image management. Tourism and Hospitality Planning E Development 7(1), 21 30. doi/10.1080/14790530903522598.

Croy, W. G., \& Walker, R. D. (2003). Rural tourism and film: Issues for strategic regional development. In D. Hall, L. Roberts \& M. Mitchell (Eds.), New directions in rural tourism (pp. 115-133).Aldershot, UK: Ashgate Publishing Ltd.

Cynthia, D. \& Beeton, S. (2009). Supporting independent film production through tourism collaboration, Tourism Review International, 13(2), 113-120. doi/10.3727/154427209789604624.

Desai, J., \& Dudrah, R. (2008). The essential Bollywood. The Bollywood Reader, 1-17. Retrieved from http://www.books.mcgraw-hill.co.uk/ openup/chapters/9780335222124.pdf.

Dudrah, R. K. (2006). Bollywood: Sociology goes to the movies (1 $1^{\text {sted.). New }}$ Delhi: Sage Publications India Pvt Ltd.

First foreign treat (2012, November 02).The Financial Express. Retrieved from http://www.financialexpress.com/news/first-foreign-treat/ 1024682.

Gursahani, M. (2008, January 09). Bollywood tourism. Retrieved from http://www.cinemalicious.com/index.php/features/117-cinema/ 324-bollywood-tourism.html. 
Harjani, P. (2011, September 19). India's tourists flock to Spain. Retrieved from http://travel.cnn.com/mumbai/life/indian-movie-boostsspanish-tourism-694426.

Hudson, S., \& Ritchie, J. R. B. (2006). Promoting destinations via film tourism: An empirical identification of supporting marketing initiatives.Journal of Travel Research,44(4), 387-396. doi: $10.1177 / 0047287506286720$.

Jha, S. K. (2005). The essential guide to Bollywood. New Delhi: Lustre Press Pvt Ltd.

Lander, S. (2010, March 4). Switzerland to woo India with Bollywood film locations tourism campaign. Travel Mail. Retrieved from http://www.dailymail.co.uk/travel/article-1255400/Switzerlandwoo-India-Bollywood-film-locations-tourism-campaign.html .

Lopez, A. (2010, April 30). A role for tourism. Financial Express. Retrieved from

http://travel.financialexpress.com/20100430/ management02.shtml.

Macionis, N. (2004). Understanding the film-induced tourist. In Frost, W., Croy, G. \& Beeton, S. (Eds.),International tourism and media conference proceedings (pp. 86-97). Melbourne: Tourism Research Unit, Monash University.

Macionis, N., \& Sparks, B. (2009). Film-induced tourism: An incidental experience. Tourism Review International, 13(2), 93-101. doi: http:/ /dx.doi.org/10.3727/154427209789604598.

Mayo, E. (1973, August). Regional images and regional behaviour. Paper presented in Travel and tourism research association, Fourth annual conference, Sun Valley, Idaho (USA).

Mayo, E. J., \& Jarvis, L. P. (1981). The psychology of leisure travel: Effective marketing and selling of travel services. Boston, Massachusetts: CBI Publishing Company.

Novaro, J. C. (2011, April 04). Fiji ups its tax incentives to $47 \%$ covering filmed production and offers new and better incentives for the commercials sector and television industry. The Business of Film. Retrieved from http://www.thebusinessoffilmdaily.com/ MIPTV2011/D1_S3.html.

O'Connor, N., Flanagan, S., \& Gilbert, D. (2008). The integration of filminduced tourism and destination branding in Yorkshire, UK. International Journal of Tourism Research, 10(5), 423-437. doi/10.1002/ jtr. 676.

Rajghatta, C. (2008, July 06). Bollywood in Hollywood. The Times of India. Retrieved from http://timesofindia.indiatimes.com/home/opinion/ 
chidanand-rajghatta/indiaspora/Bollywood-in-Hollywood/ articleshow/3201937.cms.

Riley, R. W., \& Van Doren, C. S. (1992). Movies as tourism promotion, a pull factor in a push location. Tourism Management, 13(3), 267-274. doi: 10.1016/0261-5177(92)90098-R.

Riley, R. W., Baker, D., \& Van Doren, C. S. (1998). Movie induced tourism. Annals of Tourism Research, 25(4), 919-935. doi/10.1016/S0160-7383 (98)00045-0.

Roesch, S. (2009). The experiences of film location tourists. (1sted.). Bristol, UK: Channel View Publications.

Ryan, S. (2012). Bollywood film shot in dublin expected to be watched by 100 million people. The Journal.ie, Retrieved from http://www.thejournal.ie/ bollywood-film-shot-in-dublin-expectedto-be-watched-by-100-million-people-557882-Aug2012/.

Sellgren, E. (2011). Film-induced tourism: The effect films have on destination image formation, motivation and travel behaviour. Saarbrücken, Germany: Lambert Academic Publishing.

Smith, A. (2005). Conceptualizing city image change: The 're-imaging' of barcelona. Tourism Geographies, 7(4), 398-423. doi: 10.1080/ 14616680500291188

Spain wants Indian tourists, filmmakers. (2011, September 25). eTurboNews Group. Retrieved from http://www.eturbonews.com/25411/spainwants-indian-tourists-filmmakers .

Tagliabue, J. (2012, Oct 20). Yash Chopra's love affair with Switzerland. The New York Times. Retrieved from http://movies.ndtv.com/ bollywood/yash-chopra-s-love-affair-with-switzerland-282805.

TNN (2006, Jun 26). Singapore gears up to encashKrrish. The Economic Times. Retrieved from http:// articles.economictimes.indiatimes.com/ 2006-06-26/news/.27426133_1_singapore-tourism-board-assistantchief-executive-indian-film-makers.

Tooke, N., \& Baker, M. (1996). Seeing is believing: The effect of film on visitor numbers to screened locations. Tourism Management, 17(2), 8794. doi/10.1016/0261-5177(95)00111-5

Tourism Australia. (2012). Summary of tourism Australia's 2020 India strategic plan. Retrieved from http:// www.tourism.australia.com/ documents/ Markets/India2020-June2012.pdf.

Woodside, A., \& Lysonski, S. (1989). A general model of traveller destination choice. Journal of Travel Research, 27(4), 8-14. doi: $10.1177 / 004728758902700402$. 